\title{
How Effective Can Additive Assigned Extracurricular Reading Be? More Good News
}

\author{
I-Chin Nonie Chiang \\ Foreign Language Center, National Chengchi University, Taiwan, China
}

Copyright@2018 by authors, all rights reserved. Authors agree that this article remains permanently open access under the terms of the Creative Commons Attribution License 4.0 International License

\begin{abstract}
This paper reports the effect of additive assigned extracurricular reading at the tertiary level of education in Taiwan. Chiang [1] implemented additive assigned reading after school in a college English course and used the General English Proficiency Test for the measurement of students for three consecutive academic years. The pre-/post comparison showed significant gains over all three years. The current study repeated the procedure and reported on the $4^{\text {th }}$ and the last year from of study before course reform took place. The results continuously showed significant improvement in GEPT scores between the pre-/post- tests. Implications of the results for potential factors such as reading amount and frequency are discussed.
\end{abstract}

Keywords Extracurricular Reading, Extensive Reading Graded Readers, GEPT

\section{Introduction}

Maximizing input amount is a priority for language teachers in EFL context, for language acquisition and learning only takes place when learners have sufficient input. Written input, being the predominant and most accessible input source in higher education, forms the base of other language skills. We read to learn and entertain, while the best learning situation is to learn with fun. However the learning and entertainment is balanced, the ultimate goal is to obtain proficiency development in the target language. Therefore, the current study aims to examine whether learners of an additive reading course based on the extensive reading approach made progress after an academic year and discuss its pedagogical implications.

\section{Literature Review}

Extensive reading $(\mathrm{ER})^{1}$ [4-5] research has copiously

\footnotetext{
${ }^{1}$ ER is used here to refer to reading as much as possible, similar to Free
}

yielded benefits (Appendix A) on different aspects over the past few decades. The positive effects of language acquisition through ER are empirically proven. On the other hand, the cause of acquisition regarding inputs via $\mathrm{ER}$ is less consistent. Regarding input quality, the consensus is between $\mathrm{i}-1$ and $\mathrm{i}+1$, depending on the different needs or purposes of learning. For instance, if the purpose is to help build reading interest, confidence, fluency, or vocabulary recycling, then learners should read books at the i-1 level. If the reading purpose is to increase vocabulary size, then learners will benefit more from $\mathrm{i}+1$ input. However, the extent that students should read is under discussion and in dispute. Table 1 lists suggested amounts of reading from various studies, converted the amount suggested to read into 40 weeks of the year $^{2}$ (40 weeks per school year), and ordered them from the fewest words to the most. Except the last three studies, the reading amount fell between 200,000-300,000 words per year. Despite this big goal, the participants in Suk [7] did not reach the original required amount of 200,000 words, and their reading amount varied hugely from 8,500 to 190,000 words, with the mean of 150,000 , which were estimated 400,000 after conversion in a 40-week/year. According to the ER literature, learners should read at least one book in two weeks, if one book a week is too much to handle (e.g. Nation [8]). That means 20 books in 40 weeks. If we adopt Krashen and Mason's [9] estimation of average book length being 15,000 words, 20 books will come to 300,000 words. Somehow, 300,000 words seem to become the magic number in varied ER studies. The participants' level in Suk [7] were advanced beginner to low intermediate, so they might have read slowly to target a number, which was difficult for many [9]. In Chiang's [1] study of a Taiwanese college English course, the participants' levels were higher; yet still, the target of 300,000 words would require continuous reading in summer and winter vacations. As a result, ER programs were suggested to last for longer than one year [1-2, 10-12].

Voluntary Reading [2] and Pleasure Reading [3].

The researcher was using Nation [6] as the baseline for calculation. 
Table 1. Suggested reading amount

\begin{tabular}{|c|c|c|}
\hline Research & $\begin{array}{l}\text { Suggested reading } \\
\text { amounts }\end{array}$ & $\begin{array}{c}\text { Suggested } \\
\text { reading amount } \\
\text { in school year } \\
\text { (40 weeks) }\end{array}$ \\
\hline Huffman [13] & 80,000 for 15 weeks & 213,333 \\
\hline Hagley [14] & $\begin{array}{l}85,000 \text { words for } 15 \\
\text { weeks }\end{array}$ & 226,666 \\
\hline $\begin{array}{l}\text { Nishizawa, } \\
\text { Yoshioka and } \\
\text { Fukuda [12] }\end{array}$ & $\begin{array}{c}\text { median } 690,000 \text { words in } \\
120 \text { weeks/4 years }\end{array}$ & 230,000 \\
\hline $\begin{array}{c}\text { Belgar and Hunt } \\
\text { [15] }\end{array}$ & $\begin{array}{l}200,000 \text { a year (28 times } \\
\text { of } 90 \text {-minute classes) }\end{array}$ & 285,714 \\
\hline $\begin{array}{l}\text { Nation and } \\
\text { Wang [16] }\end{array}$ & $\begin{array}{c}1 \text { graded reader }{ }^{3} \text { a week } \\
\text { (minimum } 1 \text { reader for } 2 \\
\text { weeks) }\end{array}$ & 300,000 \\
\hline $\begin{array}{l}\text { Waring and } \\
\text { McLean [17] }\end{array}$ & $\begin{array}{l}>2-3 \text { graded readers a } \\
\text { month }\end{array}$ & $\begin{array}{c}300,000 \\
\text { minimum }\end{array}$ \\
\hline Nation [6] & - & 500,000 \\
\hline Suk [7] & $\begin{array}{l}\text { 200,000 words for } 15 \\
\text { weeks }\end{array}$ & 533,333 \\
\hline Waring [18] & $\begin{array}{c}\text { 2-3 readers a week } \\
\text { (approx. 30,000-45,000 } \\
\text { words a week) }\end{array}$ & $\begin{array}{c}1,2000,000 \\
\text { minimum }\end{array}$ \\
\hline
\end{tabular}

To frame the definition and conceptualization of ER, Waring and McLean [17] suggested that there were more than 'one universal form' of ER. The derived variations included Classical ER (strictly following the Ten Principles of Day and Bamford [4]), Class reading (using class reader/texts chosen by teacher with class post-reading activities), Integrative ER (ER being a component of a skill-based course), ER as Literature (students studying the text as a piece of literature), Easy ER (reading to practice fluency and speed [19]), and ER as $\mathrm{i}+1$ (reading as source for meaning-focused input). Furthermore, four core elements must be present to qualify for the title of ER: (1) Fluent sustained comprehension of text as meaning-focused input, (2) Large volume of material, (3) Reading over extended period of time, and (4) Texts are longer, requiring comprehension at the discourse level. Most of the ER programs satisfied elements (1), (3), and (4), such as Robb and Kano [20], Nishizawa, Yoshioka and Fukuda [12, 21], and Chiang [1]. From this perspective, we can see that ER is not only about pursuing the biggest number of running words. Thus, if a beginner reader uses meaning-focused input to practice fluent reading ability, the learner is still “doing ER" [17, p.163]; even though the total number of words being read would likely to be comparatively fewer than for more advanced readers.

In the EFL context, Classical ER is rare. Most ER studies that we read about in the literature were transformed and modified into a new model to fit learner needs or contexts, e.g. integrating extracurricular extensive reading into an existing course. For example, in Japan, Robb and Kano [20] utilized students' test scores

\footnotetext{
${ }^{3}$ Based on the calculation of Krashen and Mason [9]
}

of a school-developed evaluation from two consecutive academic years to explore the impact of extracurricular reading. In their study, the 2008 cohort was not asked to read after school, while the 2009 cohort was asked to read five self-chosen readers in their own time, using the MReader platform. The 2009 cohort did improve significantly, compared to the 2008 cohort. Furthermore, Taylor [22] followed up Robb and Kano's [20] study and analyzed their data with effect size extraction. The result was impressive because the mean of the effect sizes of reading comprehension scores reached .99, which indicates that $84 \%$ of participants in the ER year (cohort 2009) should perform better than those who were not (cohort 2008). With strong evidence, Taylor advocated adding ER for university administrators who needed a simple, effective, and powerful method. This is in line with Nation's suggestion [23] of ranking extensive reading as the most significant change to a program if a teacher wants to make substantial change for a strong effect.

Krashen and Mason [9] also exploited the analysis of effect size for strong evidence. They reviewed 102 studies and concluded that students doing in-school reading (mostly sustained, silent reading) outperformed students receiving traditional instruction. The mean effect size for reading comprehension in their analysis ranged from .54 to .87 and for vocabulary from .18 to .47 [9, p.71, Table 1]. In other words, reading showed a stronger impact on reading comprehension than vocabulary.

In Taiwan, Chiang [1], based on the ER as $\mathrm{i}+1$ model [17], integrated extracurricular assigned reading into a college English course to increase student meaning-focused input. With the General English Proficiency Test (GEPT) as the research instrument, she collected the pre-/post test results from three consecutive years and the results showed significant improvement each year. This piece of evidence increased in even greater importance by adding ER to an existing course. As to the course design, Robb and Kano [20] differed from Chiang [1] in a few ways. Robb and Kano only required that learners to read any 5 books a student chooses and answers reading comprehension questions on an MReader. Student completion of this task will earn an extra five points to the final scores, which resembled the ER prototype better. Chiang, however, carefully planned the course and adopted the concept from narrow reading, used four readers and young adult novels, which were closely related to the textbook themes in addition to a self-chosen book. To evoke deeper thoughts and relevance, Chiang asked students to write a book report after they finished a book, a reflection rather than a summary, instead of comprehension tests to monitor students' reading progress. The book reports accounted for $10 \%$ of total of the student's final score. Even though $10 \%$ seemed high, because students could choose to complete these book reports in either Chinese or English, and the length was 
limited to one page only, it was an easy task for students if they finished the reading.

The work of strong believers of ER like Nishizawa, Yoshioka and Ichikawa [21] was valuable because of its length (six years). Nevertheless, their results were worrisome. In their report, students had to read to the $4^{\text {th }}$ year and more than 300,000 to feel ease at reading English, and students only reached their expected TOEIC score in Year 7. This seemed too long for most of the students and teachers; their motivation would have disappeared long before they reached their goal. Moreover, ER literature suggested lower level readers could benefit the most from ER programs, e.g. Day \& Bamford [4], however, the students in Nishizawa, Yoshioka and Ichikawa's [21] study did not seem benefit from this fast enough. Despite their careful planning of the program, the low reading frequency could be the cause of this ineffectiveness. In their study, students only read once a week, which contradicts the ER principle of receiving the input in a certain way: 'regular, frequent exposure in large quantity'. Although they tried to change the reading class from once a week into twice a week during a short period, the influence was little. However, this attempt to change the frequency should be on the right track because it increases the frequency and could easily lead to an increase in the time of exposure, if the change had been longer. So, frequency of reading may matter more than researchers have assumed. Higher frequencies of reading could help practice and maintain reading skills, and imprint in our mind [6, 24-25]. Reading regularly and frequently provides for supportive conditions for incidental learning. By frequent reading, learners have the chance to meet the words in a different context, retrieve knowledge of the words, restore them, retrieve knowledge the next time they meet them in different contexts, and enrich the knowledge to help with word retention. So, compared to increase the reading time in each session, frequency increase would be more likely to lead to larger exposure in total and proficiency improvement. In contrast, extending the reading length for each reading does not necessarily influence the frequency. Therefore, a possible reason for the abovementioned ineffectiveness is not frequent enough.

\section{Research Purpose and Questions}

Since Chiang [1] showed how effective after-school reading can be, the purpose of the current study repeated the course and tests to see whether similar results could be obtained. Also, Chiang [1] was unable to provide possible factors for the significant improvement; therefore, the current study would like to start with student reading frequency, i.e. whether they like finishing a book in one sitting or divide the reading into several occasions, and investigated the relations between the test results and reading frequency. How students deal with reading is important because one of the very important features of ER is to expose learners to the input 'constantly and regularly'. Someone who divides a book into several occasions and thus has higher frequency of reading seems to fit the ER model better than someone who finishes one book in one sitting. Previous literature suggested Taiwanese students lacked of reading habits (e.g. Chiang [26]), i.e. low frequency of written exposure; therefore, how the participants read may shed some light on the issue.

\section{Research Questions}

1. Did the students improve significantly?

2. Was there a significant correlation between the GEPT improvement and their frequency of reading?

\section{Methods}

\subsection{Participants}

This present study took place at a national university in Northern Taiwan and involved 42 non-English major freshmen, 25 males (59.5\%) and 17 females (40.5\%). The number this year was smaller because of the smaller class size and invalid information screening. Participants were on average B1 to C1 [27], similar to the sample of Chiang [1]. An informal survey of the participants' vocabulary size was carried out at the beginning of the year. Their vocabulary size ranges between 4,000 to over 9,000 word families but mostly clustered between 6,000-8,000 word families (Table 2). This sample was slightly larger than Beglar and Nation's [28] description of functioning EFL undergraduates' vocabulary size of 5,000-6,000 word families, which might have facilitated the extracurricular reading.

Table 2. Vocabulary size of the sample

\begin{tabular}{cc}
\hline Vocabulary size & Total \\
\hline $4,000-4,999$ & 2 \\
$5,000-5,999$ & 4 \\
$6,000-6,999$ & 7 \\
$7,000-7,999$ & 17 \\
$8,000-8,999$ & 7 \\
$>9,000$ & 5 \\
\end{tabular}

\subsection{Treatment}

Four graded readers and a young adult novel were assigned as extracurricular reading in the four-skilled based one-year college English course. These readers and 
novels were chosen because they related to the themes in the textbook and the students had to choose a group reading. No test was given after they read, but they were asked to write a one-page book report, either in Chinese or English, to minimize accountability. Although the original plan was to implement ER to help students cultivate an English reading habit in their leisure time, due to the heavy workload of the freshmen year and the limited resources the author had, the author compromised for the class reading model and the ER as i+1 model, instead of the Classical ER [17]. The details of the reading texts from Table 3 and Table 4 from Chiang [1] were adapted into Table 3, and examples of the students' self-selected book from Chiang [1, p.46, Table 5] were listed in Appendix B. Due to the length of the article, please see the relevant details of the course design and materials choice in Chiang [1]. This line of the study will end in the $4^{\text {th }}$ year because of course reform.

Table 3. Assigned extra-curricular reading

\begin{tabular}{|c|c|c|c|c|c|}
\hline & $\begin{array}{l}\text { Book } \\
\text { Title }\end{array}$ & Level & Head words & $\begin{array}{l}\text { Word } \\
\text { count }\end{array}$ & $\begin{array}{l}\text { Total } \\
\text { word } \\
\text { count }\end{array}$ \\
\hline 1 & $\begin{array}{c}\text { Dragon's } \\
\text { Eggs }\end{array}$ & $\begin{array}{c}\text { Cambridge } \\
\text { English } \\
\text { Reader } \\
\text { Level } 5\end{array}$ & 2,800 & 25,405 & 25,405 \\
\hline 2 & $\begin{array}{c}\text { Windows } \\
\text { of the } \\
\text { Mind }\end{array}$ & $\begin{array}{c}\text { Cambridge } \\
\text { English } \\
\text { Reader } \\
\text { Level } 5\end{array}$ & 2,800 & 25,640 & 51,045 \\
\hline 3 & Frindle & $\begin{array}{l}\text { Scholastic } \\
\text { Guided } \\
\text { Reading } \\
\text { Level: R } \\
\text { Lexile }{ }^{\circledR} \\
\text { measure: } \\
\text { 830L }\end{array}$ & $\begin{array}{c}\text { Est. } \\
4,000-6,000\end{array}$ & 16,232 & 67,277 \\
\hline 4 & $\begin{array}{l}\text { Frozen } \\
\text { Pizza }\end{array}$ & $\begin{array}{c}\text { Cambridge } \\
\text { English } \\
\text { Reader } \\
\text { Level } 5\end{array}$ & 3,800 & 26,474 & 93,751 \\
\hline
\end{tabular}

\subsection{Measures}

The General English Proficiency Test (GEPT) was developed and administered by the Language Training and Testing Center in Taiwan. It has high reliability indices (listening and reading: 0.87-0.91, inter-rater reliability indices of writing and speaking 0.89-0.90 [29]). Thus, it sustains as a valid measurement and is authenticated by many countries now. The reading section of a mock test is used in the pre-/post- test, scheduled at Week 4 of the $1^{\text {st }}$ semester and a month before the $2^{\text {nd }}$ semester ended. The reading section consists of 45 questions and the administration time was 50 minutes. The students took the tests after they gave their consent. The number of the correct answers were recorded and analyzed with SPSS.

Near the end of the $2^{\text {nd }}$ semester, a short survey regarding students' reading habit was carried out in class. One of the questions investigated students' reading frequency: "When I read these books, I tended to finish the book in one go or finish the book in several occasions." The survey contained several other questions, which were irrelevant to the current study, and thus would not be discussed here.

\section{Results}

A paired t-test was run on the sample of 42 participants to see if there was a statistically significant mean difference between the pre-/post- GEPT tests. The difference was statistically significant $(t=-2.179, \mathrm{df}=41$, $\mathrm{p}=.035<.05$ ), in line with the significant gains from the three previous years in Chiang [1, Table 6].

Table 4. GEPT gains of 4 years (including data from Chiang [1])

\begin{tabular}{|c|c|c|c|c|c|c|c|}
\hline & & \multicolumn{2}{|c|}{ Pre-test } & \multicolumn{2}{|c|}{ Post-test } & \multirow{2}{*}{ Gain } & \multirow{2}{*}{ t value } \\
\hline & & mean & s.d. & mean & s.d. & & \\
\hline \multirow{3}{*}{$\begin{array}{l}\text { Chiang } \\
\text { (2017) }\end{array}$} & $\begin{array}{c}\text { Year } \\
1\end{array}$ & 29.29 & 6.637 & 32.97 & 4.453 & 3.68 & $-5.983^{* * *}$ \\
\hline & $\begin{array}{c}\text { Year } \\
2\end{array}$ & 21.26 & 5.003 & 28.98 & 6.852 & 7.72 & $-14.282^{* * *}$ \\
\hline & $\begin{array}{c}\text { Year } \\
3\end{array}$ & 19.13 & 4.973 & 29.83 & 7.195 & 10.7 & $-12.196^{* * *}$ \\
\hline $\begin{array}{l}\text { Current } \\
\text { study }\end{array}$ & $\begin{array}{c}\text { Year } \\
4\end{array}$ & 28.50 & 8.657 & 30.45 & 7.575 & 1.95 & $-2.179^{* *}$ \\
\hline
\end{tabular}

Regarding students' reading frequency, descriptive statistics showed 8 participants chose to finish a book in one reading, while 34 finished a book in several readings. While looking into the relationship between the GEPT gains and reading frequency, bi-serial correlation was used for one variable was continuous, and the other was nominal. The test did not show a significant correlation $(\mathrm{r}=-.120, \mathrm{p}=.448>.05$, n.s. $)$.

\section{Discussion}

Regarding the first research question, the GEPT pre-/post-tests showed significant gains in the current study. While analyzing the data, the author did not expect the difference to be significant for the difference was rather small when compared to the previous study. The author tried to recollect the differences and suspected one possible modification for the course. During data collection, the course was asked to include a compulsory culture-related component. To allocate time for this component, the $5^{\text {th }}$ group reading was changed from obligatory to voluntary. Students who chose to read the $5^{\text {th }}$ book and completed a book report task will be given extra points in their final scores for encouragement, so that students could have some time to work on the relevant assignment of the culture components, such as watching the course videos, answering comprehension questions, and sharing experiences and opinions through online 
writing. In other words, the course had to replace some after-school reading input with online listening input and mostly written output. This decreased the total of quality input in general, which could reflect on the test results directly or indirectly. Even though the culture component was helpful to students in terms of cultural knowledge, the author wondered what level of vocabulary the component contained. As a result, AntWordProfiler [30], a vocabulary level analysis program, was used to analyze the vocabulary level and word count. The analysis revealed that the component used 4,358 words, and most of the vocabulary (92.1\%) was within the 2,000 word family level and academic wordlist. That is, the vocabulary was basic and easy; the input amount was a lot smaller than reading a novel/reader. Therefore, the effect of the culture component may help less than the actual reading of a novel.

On the second research of the relationship between the GEPT gains and the reading frequency, unfortunately, no significant correlation was observed. Based on the tremendous advancement of recent research on vocabulary and reading amounts, especially the work of Nation [6], the importance of frequent reading was truly revealed. He provided convincing empirical data on how extensive a learner needs to read to acquire the first $9^{\text {th }} 1,000$ word families (98\% coverage of running words in a variety of texts), in both total number of words and time length for reading every day. In terms of total of running words, we saw that research studies had set higher and higher target numbers (such as studies in Table 1 and other ER studies), which were rarely achieved. In my opinion, pursuing a yearly target of running words contradicts with the real ER essence. When readers read, they should read at their own pace. So, counting the total words being read may not be the best indicator of how well a reader is doing. Length of reading could be easily falsified by examples of occasional readings such as reading once a month. To reach the 9,000 word level, a learner needs to meet the words gradually and frequently. In Nation's calculation, a reader at the 4,000 level will need to read 17 minutes per day (at the speed of 150 words per minute) in order to learn the next 1,000 level words, 33 minutes for the 5,000 level and more than an hour for the 7,000 and above. The results point out the importance of mass input and to absorb this mass input, learners need to increase the frequency of contact exposure.

Frequent exposure may be the one simple act that we teachers need to emphasize and monitor because in a mixed class, it is common to have students of different levels. Students at different levels may need different durations for the reading to become effective [21]. It is highly probable that students with higher proficiency levels need shorter durations than their counterparts. Students at different levels should also target different vocabulary levels, so they should read books at different levels. For instance, students at higher levels need to learn the words at mid to low frequency levels. These words occur less frequently in reading texts; as a result, readers will have to read more to create enough exposure opportunities to meet the words $[6,8]$. Nonetheless, research also suggests that the reading speed slows down when readers read difficult texts because they need more time to process [31], which may suggest why depending on the total words of reading is not the best indicator. In other words, the total of running words will be influenced because we know learners at different levels or different stages read at different speeds. This has inspired the author to sketch out a reading speed timeline with several important points in time (Figure 1).

Stage 1: A learner reads slowly until they reach the homerun book experience [32]. Then, the reading speed could start to increase because of the positive experience and the confidence they gain.

Stage 2: When a learner starts reading graded readers (taking Cambridge English Readers Series as example), from the starter to Level 2, reading speed increases steadily and gradually.

Stage 3: The reader starts to enter the mid-level frequency word families, e.g. the $4^{\text {th }} 1,000$ word families (Level 3-Level 6). Due to careful and thorough vocabulary planning of graded readers, the readers should have learned the words they need to advance to the higher level in the series without major difficulties. Also, with the accumulation of the reading experiences, a reader should be able to read faster than the stage before.

Stage 4: After the graded readers, the readers continue to read mid-frequency readers or young adult novels. However, at this stage, since the target vocabulary level has entered the low frequency level, reading speed may slow down a little than the previous stage again.

Stage 5: Finally, the reader will start to read non-simplified novels. The reading speed here is more likely to fluctuate dramatically in response to the levels of text difficulties. When easier books are read, the speed will be higher and vice versa. Uden, Schmitt, and Schmitt [33] showed that graded readers were slightly lower than novels regarding vocabulary coverage. Thus, when the reading texts were changed from graded readers into ungraded novels, the vocabulary coverage would drop from $99 \%$ to $95 \%$, which could influence reading speed and comprehension. After stage 5, the reading speed would become native-like and stable, which will have the highest speed. ${ }^{4}$

\footnotetext{
${ }^{4}$ Figure 1 shows the overall rising tendency for reading speed. This is because the author is making the sketch based on the ER approach: With the accumulation of positive reading experiences, readers can read faster and faster. Of course, the author recognizes that occasionally setbacks related to speed and exceptional cases occur; however, in the long run, there are no doubts about the upward trend.
} 


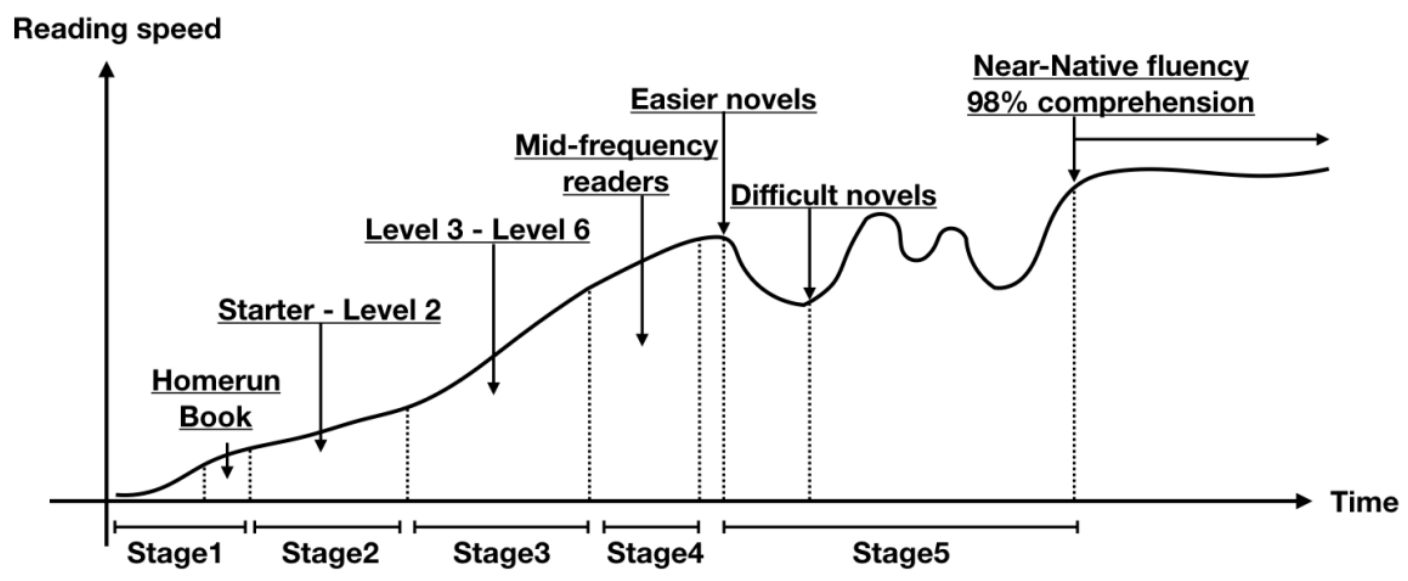

Figure 1. Reading speed development

Bearing all these in mind while facing a large multi-level class, the teacher should consider the principle of frequent reading as a feasible first step. Being able to keep reading is key to increasing reading fluency for only it can provide enough repetition, which can in turn provide feedback for an increase of fluency [15, p.32], because the elements to fluency are in consistent practice, repetition of embedded linguistic form in communication contexts, and implementation over a long period of time [15]. Highly motivated students would do anything to keep themselves advancing, while less motivated students need a teacher's monitoring [20].

Since frequent target language exposure is so important, how likely is it for Taiwan universities to ask students to take English courses or do ER throughout the four years, like Nishizawa, Yoshioka and Ichikawa [21] asked their students? My answer unfortunately is not very positive. In the institution that the author works for, the course structure changes from two hours a week (2 credits) to three hours a week (3 credits). Since the students only need six credits for English, they could shorten their English course from three semesters to two semesters. Students who wish to stop taking English courses could do so after their first year. The consequence of this change could lead to sole dependence of the unstable motivation and willingness. Even though the university established all sorts of English taught programs in subjects to make up for this, we still cannot be sure how much this helps English learning along with their professional knowledge. As a result, I think it is essential and urgent for ER researchers and practitioners to declare the importance of this approach and take actual action in their practice.

\section{Conclusions}

A good language program should include both message-focused learning as well as an appropriate amount of deliberate learning [8, 19, and 25]. Extracurricular reading in the current study supported the additive ER program after school for it provided "An essential condition for learning is repetition" [6, p.2]. To have enough meetings to learn a word, learners must keep reading as much as possible and as frequently as possible, but at their own pace.

The results of the present study should be taken as suggestive and interpreted with caution because it is small-scaled, does not have more details regarding frequency for further analysis, Thus, the advice for future studies is that the study must be replicated with modifications such as a larger population of learner. Then, the future researchers should collect detailed and reliable frequency data for further analysis. For example, the researchers could consider comparing data collected from groups of various reading frequency with a control group for design improvement.

\section{Appendix A}

Table 5. ER Benefits

\begin{tabular}{|c|l|}
\hline & \multicolumn{1}{|c|}{ Literature } \\
\hline Vocabulary & $\begin{array}{l}\text { Lee [34-35], Ponniah [36], Waring \& } \\
\text { Nation [37], Wang [38], Chang \& Hu [39], } \\
\text { Pigada \& Schmitt [40] }\end{array}$ \\
\hline Reading level & Mermelstein [41] \\
\hline Syntax & Cho \& Krashen [42], Nation [43] \\
\hline $\begin{array}{c}\text { Linguistic } \\
\text { structures }\end{array}$ & $\begin{array}{l}\text { Song \& Sardegna [44] on prepositions, } \\
\text { Resketis \& Bagheri [45] on phrasal verbs }\end{array}$ \\
\hline Self-confidence & Iwahori [46] \\
\hline $\begin{array}{c}\text { Reading fluency } \\
\text { Motivation } \\
\text { [13] }\end{array}$ & $\begin{array}{l}\text { Takase [48], Arnold [49], Wong \& Nunan } \\
\text { [50] }\end{array}$ \\
\hline $\begin{array}{c}\text { Listening \& } \\
\text { speaking }\end{array}$ & Cho \& Krashen [42], Mason [51-55] \\
\hline Writing & Elley [56], Lai [57], Tudor and Hafiz [58] \\
\hline $\begin{array}{c}\text { TOEFL } \\
\text { improvement }\end{array}$ & $\begin{array}{l}\text { Constantino, Lee, Cho \& Krashen [59], } \\
\text { Gradman \& Hanania [60], Mason [61-62] }\end{array}$ \\
\hline $\begin{array}{l}\text { Krashen \& Mason [63], Mason [64-65], } \\
\text { Mason \& Krashen [66], Nishizawa, } \\
\text { Yoshioka \& Fukuda [12, 21], Storey, } \\
\text { Gibson \& Williamson [67] }\end{array}$ \\
\hline
\end{tabular}




\section{Appendix B}

Table 6. Total word count of readings from Chiang [1]

\begin{tabular}{|c|c|c|}
\hline & $\begin{array}{c}\text { Self-Selected Novels } \\
\text { Word count }\end{array}$ & $\begin{array}{c}\text { Total word } \\
\text { count }\end{array}$ \\
\hline $\begin{array}{c}\text { Assigned graded } \\
\text { readers and Frindle }\end{array}$ & & 93,751 \\
\hline Self-Selected Novels & & \\
\hline Dolphin Music & 23,267 & 117,018 \\
\hline Murder Maker & 28,170 & 121,921 \\
\hline Who Stole My Cheese & 29,760 & 123,511 \\
\hline The Giver & 43,617 & 137,368 \\
\hline Charlotte's Web & 59,520 & 153,271 \\
\hline Tuesdays with Morrie & 59,520 & 153,271 \\
\hline Diary of a Wimpy Kid & 69,440 & 163,191 \\
\hline $\begin{array}{c}\text { Harry Potter \& the } \\
\text { Sorcerer's Stone }\end{array}$ & 77,508 & 171,259 \\
\hline Twilight & 168,640 & 262,391 \\
\hline \multicolumn{2}{|c|}{} \\
\hline
\end{tabular}

\section{REFERENCES}

[1] I. N. Chiang. GEPT Gains Using Extra-Curricular English Reading, International Journal of Language and Linguistics, Vol.4, No.4, 41-54, 2017.

[2] S. Krashen. The power of reading, Libraries Unlimited. U.S.A., 2004.

[3] R. Constantino. Pleasure reading helps, even if readers don't believe it, Journal of Reading, Vol.37, 504-505, 1994.

[4] R. Day, J. Bamford. Extensive reading in the second language classroom, Cambridge University Press, UK, 1998.

[5] F. M. Hafiz, I. Tudor. Extensive reading and the development of language skills, ELT Journal, Vol.43, 4-13, 1989.

[6] P. Nation. How much input do you need to learn the most frequent 9,000 words? Reading in a Foreign Language, Vol.26, No.2, 1-16, 2014.

[7] N. Suk. The effects of extensive reading on reading comprehension, reading rate, and vocabulary acquisition, Reading Research Quarterly, Vol.52, No.1, 73-89, 2016.

[8] P. Nation. Principles guiding vocabulary learning through extensive reading, Reading in a Foreign Language, Vol.27, No.1, 136-145, 2015.

[9] S. Krashen, B. Mason. Sustained Silent Reading in Foreign Language Education: An Update, Turkish Online Journal of English Language Teaching, Vol.2, No.2, 70-73, 2017.

[10] N. Carney. Gauging Extensive Reading's Relationship with TOEIC Reading Score Growth, Journal of Extensive Reading, Vol.26, No.4, 69-86, 2016.

[11] T. Nikanishi. A meta-analysis of extensive reading research, TESOL Quarterly, Vol.49, No.1, 6-37, 2015.
[12] H. Nishizawa, T. Yoshioka, M. Fukada. The impact of a 4-year extensive reading program. In A. M. Stoke (Ed.), JALT 2009 Conference Proceedings, Tokyo, 2010.

[13] J. Huffman. Reading rate gains during a one-semester extensive reading course, Reading in a Foreign Language, Vol.26, 17-33, 2014.

[14] E. Hagley. Extensive graded reading with engineering students: Effects and outcomes, Reading in a Foreign Language, Vol.29, No.2, 203-217, 2017.

[15] D. Belgar, A. Hunt. Pleasure reading and reading rate gains, Reading in a Foreign Language, Vol.26, 29-48, 2014.

[16] P. Nation, K. Wang. Graded readers and vocabulary, Reading in a Foreign Language, Vol.12, 355-380, 1999.

[17] R. Waring, S. McLean. Exploration of the core and variable dimensions of extensive reading research and pedagogy, Reading in a Foreign Language, Vol.27, No.1, 160-167, 2015.

[18] R. Waring. What kind of vocabulary is in course books and graded readers? Paper at the Vocab@Vic Conference, December, 2013. Victoria University Wellington, New Zealand, 2013.

[19] P. Nation. The Four Strands, Innovation in Language Learning and Teaching, Vol.1, 1-12, 2007.

[20] T. Robb, M. Kano. Effective extensive reading outside the classroom: A large-scale experiment, Reading in a Foreign Language, Vol.25, 234-247, 2013.

[21] H. Nishizawa, T. Yoshioka, M. Fukada. Effect of a six-year long extensive reading program for reluctant learners of English, Modern Journal of Language Teaching Methods, Vol.7, No.8, 116-123, 2017.

[22] T. Taylor. How effective can extensive reading be? Comments on Robb and Kano (2013), Reading in a Foreign Language, Vol.26, No.1, 195-198, 2014.

[23] P. Nation. What does every ESOL teacher need to know? Closing plenary address at the 2012 CLESOL conference in Palmerston North. The TESOLANZ Journal, Vol.20, 1-7. Online Available: http://www.tesolanz.org.nz/Site/Publicati ons/TESOLANZ_Journal/

[24] I. N. Chiang. The habitual domain, brain research and language learning, Journal of Habitual Domains, No.4, No.1, 43-56, 2012.

[25] P. Nation. Designing reading tasks to maximize vocabulary learning, Applied Research on English Language, Vol.3, No.1, 1-8, 2013a.

[26] I. N. Chiang. Extra-Curricular Reading in Taiwan, Asian EFL Journal, Vol.80, pp.4-33, 2014.

[27] Council of Europe. Common European Framework of Reference for Languages: Learning, teaching, assessment, Cambridge University Press, Cambridge, 2001.

[28] D. Belgar, P. Nation. A vocabulary size test, The Language Teacher, Vol.31, 9-13, 2007.

[29] C. Roever, Y. Pan. GEPT: General English Proficiency Test, Language Testing, Vol.25, No.3, 403-418, 2008.

[30] L. Anthony. AntWordProfiler (Version 1.4.1) [Computer Software]. Tokyo, Japan: Waseda University. [Online] Available http://www.laurenceanthony.net/software 
[31] S. Crossley, H. Yang, D. McNamara. What's so simple about simplified texts? A computational and psycholinguistic investigation for text comprehension and text processing, Reading in a Foreign Language, Vol.26, No.1, 92-113, 2014.

[32] J. Trelease. The read-aloud handbook (4th ed.), Penguin, New York, 2001.

[33] J. Uden, D. Schmitt, N. Schmitt. Jumping from the highest graded readers to ungraded novels: Four case studies, Reading in a Foreign Language, Vol.26, No.1, 1-28, 2014.

[34] S. Lee. The Robustness of Extensive Reading: Evidence from Two Studies, The International Journal of Foreign Language Teaching, Vol. Summer, 13-24, 2005a.

[35] S. Lee. Sustained Silent Reading Using Assigned Reading: Is Comprehensible Input Enough? The International Journal of Foreign Language Teaching, Vol. Fall, 10-12, 2005b.

[36] J. Ponniah. Incidental acquisition of vocabulary by reading, The Reading Matrix, Vol.11, 135-139, 2011.

[37] R. Waring, P. Nation. Second language reading and incidental vocabulary learning, Angles on the English Speaking World, Vol.4, 97-110, 2004.

[38] Y. Wang. Incidental vocabulary learning through extensive reading: A case of lower-level EFL Taiwanese learners, The Journal of Asian TEFL, Vol.10, No.3, 59-80, 2013.

[39] A. C-S. Chang, H. M-C. Hu, Learning Vocabulary through Extensive Reading: Word Frequency Levels and L2 Learners' Vocabulary Knowledge Level, the Electronic Journal for English as a Second Language, Vol.22, No.1, 2018. Online Available:http://www.tesl-ej.org/wordpress/i ssues/volume22/ej85/ej85a1/

[40] M. Pigada. N. Schmitt. Vocabulary acquisition from extensive reading: A case study, Reading in a Foreign Language, Vol.18, No.1, 1-28, 2006.

[41] A. D. Mermelstein. Improving EFL Learners' Reading Levels through Extensive Reading, The Reading Matrix, Vol.14, No.2, 227-242, 2014.

[42] K. Cho, S. Krashen. Acquisition of vocabulary from the Sweet Valley Kids series: Adult ESL acquisition, The Journal of Reading, Vol.37, 662-667, 1994.

[43] P. Nation. The language learning benefits of extensive reading, The Language Teacher Online, Vol.21, No.5, 13-16, 1997.

[44] J. Song, V. G. Sardegna. EFL Learners' Incidental Acquisition of English Prepositions through Enhanced Extensive Reading Instruction, RELC, Vol.45, No.1, 67-84, 2014.

[45] B. Resketis, B. Bagheri. EFL Learners' Incidental Acquisition of English Phrasal Verbs through Enhanced Extensive Reading vs. Unenhanced Extensive Reading, International Journal of Foreign Language Teaching \& Research, Vol.2, No.8, 33-42, 2014.

[46] Y. Iwahori. Developing reading fluency: A study of extensive reading in EFL, Reading in a Foreign Language, Vol.20, 70-91, 2008.

[47] W. Grabe. Fluency in reading - Thirty-five years later,
Reading in a Foreign Language, Vol.22, 71-83, 2010.

[48] A. Takase. The impact of extensive reading on reluctant Japanese EFL learners, The European Journal of Applied Linguistics and TEFL, Vol.1, 97-113, 2012.

[49] N. Arnold. Online extensive reading for advanced foreign language learners: An evaluation study, Foreign Language Annals, Vol.42, No.2, 340-366, 2009.

[50] L. Wong, D. Nunan. The learning styles and strategies of effective language learners, System, Vol.39, 144-163, 2011.

[51] B. Mason. The Efficiency of Self-Selected Reading and hearing Stories on Adult Second Language Acquisition, 2007a. Online Available: http://benikomason.net/content/a rticles/the_efficiency_of_self-selected_reading_and_hearin g_stories_on_adult_second_language_acquisition.pdf

[52] B. Mason. Substantial Gains in Listening and Reading Ability in English as a Second Language from Voluntary Listening and Reading in a 75 Year Old student, 2013a. Online Available: http://benikomason.net/content/articles/s ubstantial_gains_b_mason.pdf

[53] B. Mason. The Case of Mr. Kashihara: Another Case of Substantial Gains in Reading and Listening without Output or Grammar Study, 2013b. Online Available: http://beniko mason.net/content/articles/mr_kashihara.pdf

[54] B. Mason. The Efficient Use of Literature in Second Language Education: Free Reading and Listening to Stories, 2013c. Online Available: http://benikomason.net/content/ar ticles/the_efficient_use_of_literature_in_second_language _education.pdf

[55] B. Mason. Self-Selected Pleasure Reading and Story Listening for Foreign Language Classrooms, 2014. Online Available: http://benikomason.net/content/articles/ibukiyo march2014.pdf

[56] W. B. Elley. Acquiring literacy in a second language: the effect of book-based programs, Language Learning, Vol.41, No.3, 375-411, 1991.

[57] F-K. Lai. The effect of a summer reading course on reading and writing skills, System, Vol.21, 87-100, 1993.

[58] I. Tudor, F. Hafiz. Extensive reading as a means of input to L2 learning, Journal of Research in Reading, Vol.12, 164-178, 1989.

[59] R. Constantino, S. Y. Lee, K. Cho, S. Krashen. Free Voluntary Reading as a Predictor of TOEFL Scores, Applied Language Learning, Vol.8, No.1, 111-118, 1997.

[60] H. Gradman, E. Hanania. Language learning background factors and ESL proficiency, Modern Language Journal, Vol.75, 39-51, 1991.

[61] B. Mason. Free Voluntary Reading and Autonomy in Second Language Acquisition: Improving TOEFL Scores from Reading Alone, 2006. Online Available: http://beniko mason.net/content/articles/improving_toefl_scores_from_r eading_alone.pdf

[62] B. Mason. TOEFL Preparation using Recreational Reading, 2007b. Online Available: http://benikomason.net/content/a rticles/toefl_preparation_using_recreational_reading.pdf

[63] S. Krashen, B. Mason. Can Second Language Acquirers 
Reach High Levels of Proficiency Through Self-Selected Reading? An Attempt to Confirm Nation's (2014) Results, 2015. Online Available:http://benikomason.net/content/arti cles/2015_krashen_mason_can_second_language_acquirer s__.pdf

[64] B. Mason. The effect of adding supplementary writing to an extensive reading program, 2004. Online Available: http://www.benikomason.net/content/articles/effect_of_ad ding_supplementary_writing_to_an_extensive_reading_pr ogram.pdf

[65] B. Mason. Impressive gains on the TOEIC after one year of comprehensible input, with no output or grammar study,
2011. Online Available: http://benikomason.net/content/art icles/mason_tanaka_ijflt_11-11.pdf

[66] B. Mason, S. Krashen. Self-Selected Reading and TOEIR Performance: Evidence from Case Histories, 2017. Online Available: http://benikomason.net/content/articles/self-sele cted_reading_and_toeic_performance:_evidence_from_cas e_histories.pdf

[67] C. Storey, K. Gibson, R. Williamson. Can extensive reading boost TOEIC scores? In K. Bradford-Watts, C. Ikeguchi, \& M. Swanson (Eds.) JALT 2005 Conference Proceedings, Tokyo, 2006. Online Available: http://jalt-publications.org/ archieve/pro-ceedings/2005/E034.pdf 